\title{
Estimation of shallow S-wave velocity structure and site response characteristics by microtremor array measurements in Tekirdag region, NW Turkey
}

\author{
Ozlem Karagoz ${ }^{1,2^{*}}$, Kosuke Chimoto', Seckin Citak ${ }^{3}$, Oguz Ozel ${ }^{4}$, Hiroaki Yamanaka ${ }^{1}$ and Ken Hatayama ${ }^{5}$
}

\begin{abstract}
In this study, we aimed to explore the S-wave velocity structure of shallow soils using microtremors in order to estimate site responses in Tekirdag and surrounding areas (NW Turkey). We collected microtremor array data at 44 sites in Tekirdag, Marmara Ereglisi, Corlu, and Muratlı. The phase velocities of Rayleigh waves were estimated from the microtremor data using a Spatial Autocorrelation method. Then, we applied a hybrid genetic simulated annealing algorithm to obtain a 1D S-wave velocity structure at each site. Comparison between the horizontal-to-vertical ratio of microtremors and computed ellipticities of the fundamental mode Rayleigh waves showed good agreement with validation models. The depth of the engineering bedrock changed from 20 to $50 \mathrm{~m}$ in the Tekirdag city center and along the coastline with a velocity range of 700-930 m/s, and it ranged between 10 and $65 \mathrm{~m}$ in Marmara Ereglisi. The average S-wave velocity of the engineering bedrock was $780 \mathrm{~m} / \mathrm{s}$ in the region. We obtained average S-wave velocities in the upper $30 \mathrm{~m}$ to compare site amplifications. Empirical relationships between the AVs30, the site amplifications, and also average topographic slopes were established for use in future site effects microzonation studies in the region.
\end{abstract}

Keywords: AVs30; Microtremor array observation; Phase velocity; Shear-wave velocity; Site amplification; Slope; Tekirdag

\section{Background}

Destructive earthquakes in the past have shown that local site conditions have major effects on ground shaking. S-wave velocity $(V s)$ structure is an important parameter in site amplification calculations for earthquake damages scenarios.

Estimation of $V s$ profiles with direct methods, like borehole and drilling, requires geophysical or laboratory testing and imposes significant cost and time constraints. However, there are simple, economical, and rapid indirect methods to evaluate $V s$ profiles, like spectral ratios of horizontal-to-vertical components $(\mathrm{H} / \mathrm{V})$

\footnotetext{
*Correspondence: karagoz.o.aa@m.titech.ac.jp

'Department of Environmental Science and Technology, Tokyo Institute of Technology, Tokyo, Japan

${ }^{2}$ Department of Geophysical Engineering, Çanakkale Onsekiz Mart University, Çanakkale, Turkey

Full list of author information is available at the end of the article
}

and microtremor array data analyses. Microtremor observations have become very popular because they are cost effective and rely on easily collected data for site characterization in terms of microzonation mapping (e.g., Kudo et al. 2002; Ozel et al. 2004; Zor et al. 2010; Grutas and Yamanaka 2012; Zaineh et al. 2012; Asten et al. 2014).

The importance of site effect studies has been more widely recognized since the 1999 Kocaeli Earthquake (Mw 7.4) in Marmara Region (NW Turkey), especially in the Istanbul megacity. There have been several site effect studies for Istanbul, Kocaeli, and Bursa cities. Although the Avcilar district of Istanbul in the western part of the city is $\sim 150 \mathrm{~km}$ far from the Kocaeli earthquake epicenter, many buildings collapsed during the earthquake. This demonstrates that even places distance from an earthquake source cannot be considered safe. Ozel et al. (2002, 2004), Kudo et al. (2002), Ergin et al. (2004), 
Bozdag and Kocaoglu (2005), and Kilıç et al. (2006) studied site effects in western Istanbul (Avcilar, Yesilkoy, Bakirkoy, Zeytinburnu districts) using aftershock and microtremor records. They reported the existence of low S-wave velocities $(\sim 200 \mathrm{~m} / \mathrm{s})$ for shallow layers and high amplifications at low frequencies $(<5 \mathrm{~Hz})$. Site effects in the Kocaeli metropolitan area were also investigated in detail (Zor et al. 2010; Ozalaybey et al. 2011) and the 3D structure of the basin mapped. Gok and Polat (2012) studied site effects in Bursa city. However, there has been no comprehensive site effect study in the western side of the Marmara Region.

Our study area covers a rapidly growing part of Turkey and encompasses the main financial and industrial centers, including Istanbul which is one of the most populated cities in the world. In this study our target area was Tekirdag, the second largest province $(150 \mathrm{~km}$ away from Istanbul) located on the north-western coastline of the Sea of Marmara with space available for future increases in urbanization and industrialization. Although Tekirdag is close to Istanbul, there have been no studies to define shallow velocity structures to the engineering bedrock for the city.

The main objective of this study was to explore the 1D Vs layer structures of shallow depths $(0-100 \mathrm{~m})$ from microtremor explorations in Tekirdag for future engineering applications. We investigated S-wave velocity profiles using phase velocities of Rayleigh waves and a hybrid inversion technique. Using the profiles, we discuss the site amplification in Tekirdag city and surrounding areas.

\section{Geological settings}

Turkey is located between the three main tectonic plates: Eurasia, Arabia, and Africa. Due to the Eurasian-Arabian continental collision in the east and extensional regime in the Aegean, the Anatolian Palate escapes to the west between the North and East Anatolian strike-slip fault systems as shown in Fig. 1a. The North Anatolian Fault Zone (NAFZ) is a 1200-km-long right-lateral strike-slip fault system between the Eurasian and Anatolian plates and is capable of generating several destructive earthquakes $(M>7)$. It cuts the Sea of Marmara in roughly east-west direction (i.e., Ketin 1948; Şengör 1979; Barka 1992; Fig. 1a). The important point is that the segments of the NAFZ are very close to highly populated cities including our research area. The NAFZ has a uniform slip-rate of $\sim 25 \mathrm{~mm} /$ year (McClusky et al. 2000) and releases the accumulated seismic energy with large earthquakes $(M>7)$. According to historical records, the area has been frequently visited by destructive earthquakes (Ambraseys and Finkel 1995). The last two significant earthquakes occurred in the western (9 August $1912 \mathrm{Mw} 7.4$ ) and eastern (17 August $1999 \mathrm{Mw}$ 7.4) parts of the Marmara region
(Fig. 1a). The distance between the North Anatolian Fault Zone and Tekirdag is about $20 \mathrm{~km}$, and the coastline of Tekirdag is considered vulnerable to a possible major earthquake like Istanbul.

A detailed geology map of Tekirdag is given in Fig. 1b (Tekirdag Municipality, 2006). Tekirdag city is located on the southern part of the Thrace Basin. The study area is generally covered by Oligocene-Lower Miocene continental clastic rocks (siltstone, claystone, sandstone). There are also wide artificial landfill areas beneath the city center. The coastline between Tekirdag and Marmara Ereglisi consists of Middle-Upper Oligocene aged claystone, sandstone, and siltstone unites of the Danisment Formation (Fig. 1b). The elevation of topography increases from the coastline to the north as high as $200 \mathrm{~m}$. The younger units are visible at higher elevations. There are also several N-S oriented creek beds filled with Quaternary soil. The alluvial bed of Cevizli Creek is the largest in the west of the city. Landfills were located in the city center of Tekirdag. The coastline is also covered with artificially filled areas to enlarge the main road and city park. The downtown of the city (around the site T04 in Fig. 1b) is covered by old city landfill on the claystone units.

\section{Methods}

\section{Array measurements of microtremors}

The microtremor measurement sites were deployed on different geological units as shown in Fig. 1b. T02, T08, T24, and T31 were located on claystone, T09, T23, T29, and T32 on the sandstone, and T21, T25, T03, T10, and T33 on the silt stone unit. We also had 3 sites (T04, T07, and T01) on the landfill, 4 sites on the clay-sand stone (T06, T11, T26, and T27) and 8 sites located on the alluvial units (T05, T20, T22, T13, T12, T28, T19, and T18).

There is no detailed geology map for the other three districts: Marmara Ereglisi, Muratll, and Corlu. These areas consist of similar continental clastic rocks mainly in Miocene age according to information in the 1:500,000 large scaled geology map of Turkey from the General Directorate of Mineral Research and Exploration (MTA 2002) web page (Fig. 1b). This geological unit contains 14 sites (e.g., T14, T39, T44, T41). Muratl and Corlu lie near the Ergene River which is one of the largest river in Thrace. We had only 7 sites in the northern part of the city.

We performed field studies to collect microtremor data using double triangular array configurations in October 2013 and September 2014 (Fig. 2). This data was used to determine S-wave velocity structures of shallow soil formations in order to perform site effect analysis. The array measurements were carried out at 44 locations in Tekirdag. There were two sites, T46 and T47, located at Gazikoy and Sarkoy (SW Tekirdag), respectively. We did 

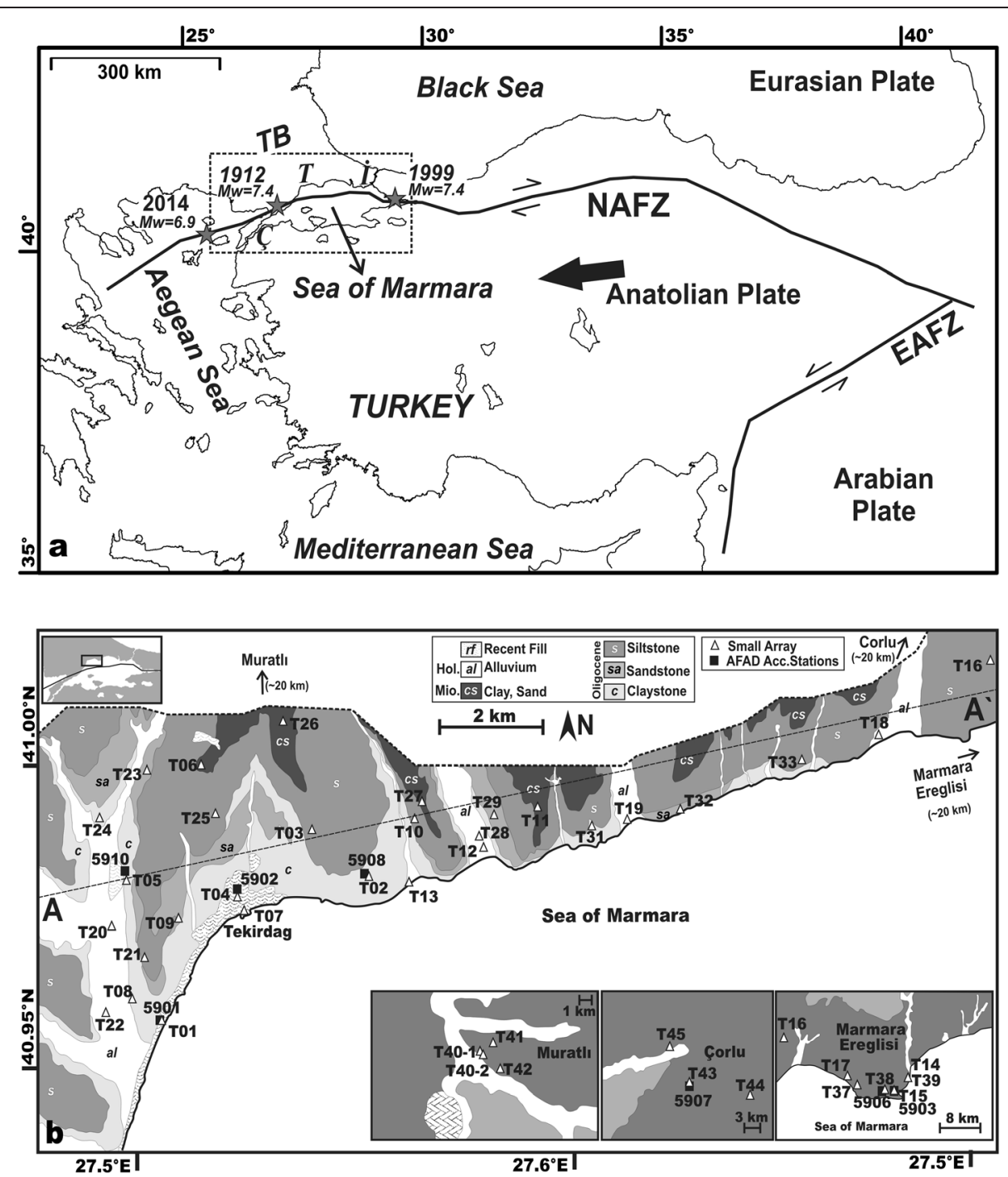

Fig. 1 a Main tectonic units and fault systems in Turkey. The study area is shown with rectangle. Ç: Çanakkale, I: Istanbul, T: Tekirdag. EAFZ East Anatolian Fault Zone, NAFZ North Anatolian Fault Zone, TB Thrace Basin. Stars show the significant earthquakes in the last century. b Detailed geology map of Tekirdag redrawn from the 1:12,000-scaled map of Tekirdag Municipality (2006), Muratli, Corlu, and Marmara Ereglisi regions are redrawn from MTA (2002) web page http://www.mta.gov.tr/v2.0/daire-baskanliklari/jed/index.php?id=500bas) 1:500,000 Istanbul Geology Map. White triangles are small array observation sites; black squares are AFAD (Republic of Turkey Prime Ministry Disaster \& Emergency Management Presidency Earthquake Department) strong motion stations

not use results of these two sites that were located 30 and $50 \mathrm{~km}$ far from the city center during the interpretation.

The sites were deployed away from roads with hightraffic, factories, main bus stations, and other man-made temporary noise sources in order to record accurate data. We chose strong motion station locations of the Republic of Turkey Prime Ministry Disaster \& Emergency Management Presidency (AFAD) Earthquake Department, schools, parks, governmental, or private lands for easy deployment of the circular arrays (Fig. 1b).

We used V243S (Mitsutoyo Corp.) accelerometers with a flat characteristic frequency range of 0.20 and $25 \mathrm{~Hz}$. Seven vertical sensors were used in each array (Fig. 2a).
Data were recorded with 24-bit analog-to-digital (A/D) wireless recorders with 100 samples per second. The SPAC method, in practice, requires a circular array consisting of three or more circumferential stations and one at the center (Okada 2006). At least three sensors located at the edge of the equilateral triangle inscribed in a circle and one sensor at the center are sufficient for SPAC applications to provide phase velocities (Kudo et al. 2002). For this reason, we temporally deployed six vertical accelerometers at the edge of the two equilateral triangles inscribed in large and small circles, and a three components accelerometer was deployed at the center of the array (Fig. 2b). The maximum and minimum lengths of 

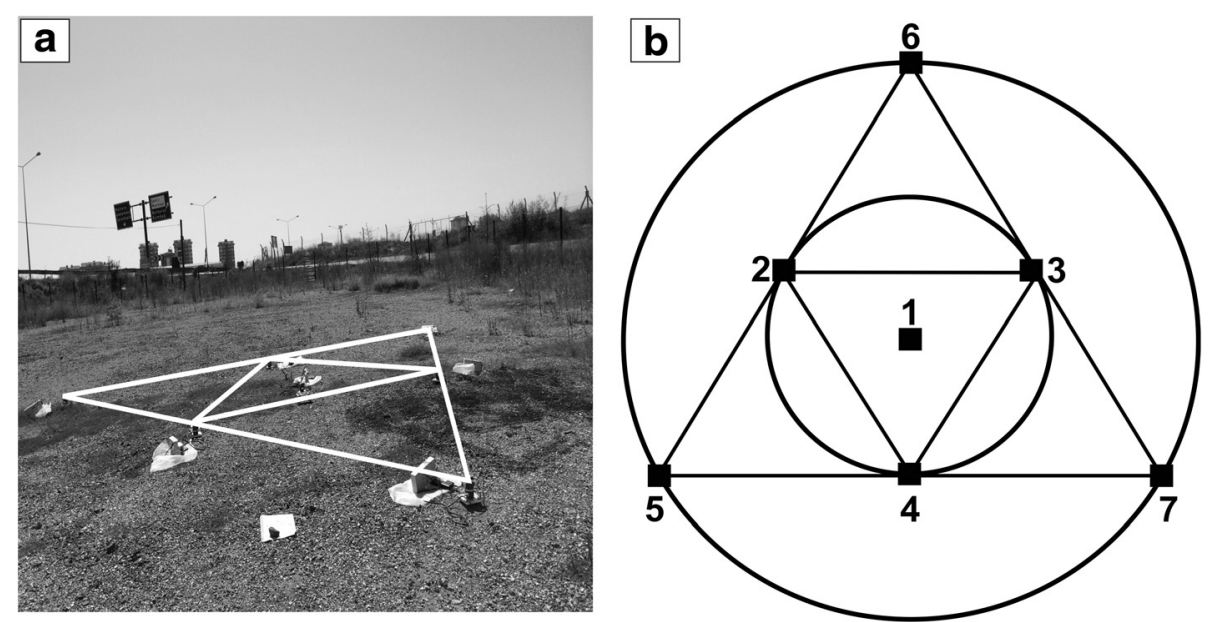

Fig. 2 a Example of vertical configuration at T22 (24-3 m). b Circular small array configuration. Numbers show accelerometers location

the sides of equilateral triangles were 32 and $2 \mathrm{~m}$, respectively, as shown in Table 1 . The array size was controlled by the availability of open space. The maximum array size possible was $32 \mathrm{~m}$ because of the wireless LAN data transmission limitation. The detail of the observation system can be seen in Grutas and Yamanaka (2012). The record lengths of the microtremors were at least 15 or $20 \mathrm{~min}$ for each array. Information on the sites and the parameters obtained in this study are given in Table 1.

\section{Estimation of phase velocities}

Phase velocities of Rayleigh waves were estimated from vertical components of microtremors using the SPAC method proposed by Okada (2003). The SPAC method computes cross-correlations between station pairs in the array with the SPAC coefficients for calculation of phase velocity at different frequencies. Each verticalcomponent record was divided into $81.92 \mathrm{~s}$ time segments. Then, the transient and artificial noises generated by local conditions such as pedestrians and cars near the sensors during the measurements were removed. The Parzen window with a band width of $0.2 \mathrm{~Hz}$ was chosen for smoothing in the data processing. We used the 6-14 segments (average 10) for averaging to get the phase velocity at each frequency. Further details on our data process can be found in previous studies (Grutas and Yamanaka 2012; Zaineh et al. 2012).

Figure 3 shows an example of the SPAC coefficients obtained from the microtremor data recorded at site T22. Depending on the array configuration, the five SPAC coefficients corresponding to the five sensor pair distances were calculated. The calculated SPAC coefficients are high enough at a frequency up to $1.5 \mathrm{~Hz}$ (Fig. 3). Different distances between the sensor pair help us to get information from different frequency ranges. While the low frequency information is from the SPAC coefficients of large distance $(24 \mathrm{~m})$, high frequency information can be observed from the small distance $(6.92 \mathrm{~m})$. Therefore, it is possible to obtain information corresponding to different depths.

The sites were distributed on seven different surface geological units at the city center and along the coastline in Tekirdag (Fig. 1b). We classified observed phase velocities dispersion curves at the sites according to the geological units. The eight groups $(\mathrm{a}-\mathrm{h})$ are shown in Fig. 4. Group a contained sites located on alluvial areas. Sites T22 and T19 had low phase velocities $(\sim 400 \mathrm{~m} / \mathrm{s})$ at lower frequencies that represent deep parts of the sediment layer. The dispersion curve of T05 was very steep with respect to the other sites, and the highest velocity $(\sim 625 \mathrm{~m} / \mathrm{s})$ at low frequencies was observed there. Group a showed wide frequency ranges of the phase velocities $(2-30 \mathrm{~Hz})$. T22, T20, and T05 were on the alluvial bed of the Cevizli Creek in Tekirdag city, and it can be clearly seen that their dispersion curves showed steep variations with increasing frequency, suggesting the variation in thickness of the alluvial bed from the coast (T22) to the upriver (T05). There are several small alluvial creek beds in the east of Tekirdag. The dispersion curves of T12, T13, T18, T19, and T28 changed due to the differing thickness of the alluvial sediments. The lowest velocity was $\sim 90 \mathrm{~m} / \mathrm{s}$ (T18), and the velocities increase up to $625 \mathrm{~m} / \mathrm{s}$ at lower frequencies at these sites.

The three sites in group $b$ in the area covered by landfill had phase velocities between 165 and $600 \mathrm{~m} / \mathrm{s}$. The frequency band was narrow $(6-30 \mathrm{~Hz})$. The dispersion curve of T04 was steep at high frequencies because the site was located on a hillside. The others were on the landfill along the coastline of Tekirdag city center (Fig. 1b).

Group $c$ represents the phase velocities at the sites deployed on claystone. The phase velocities were between 230 and $700 \mathrm{~m} / \mathrm{s}$ in frequency ranges larger than $5 \mathrm{~Hz}$. 
Table 1 Station code, latitude, longitude, elevation, average slope, surface geology index (GI), array sizes of microtremor measurements, AVs30 values, and NEHRP site class

\begin{tabular}{|c|c|c|c|c|c|c|c|c|c|c|}
\hline Station & Lat. $\left({ }^{\circ} \mathrm{N}\right)$ & Long. ( $\left.{ }^{\circ} \mathrm{E}\right)$ & Elev. (m) & Ave. slope & $\mathrm{Gl}$ & $\begin{array}{l}\text { Small array side } \\
\text { sizes }(m)\end{array}$ & $\mathrm{AVs} 30(\mathrm{~m} / \mathrm{s})$ & NEHRP site class & Ave. Ampl $(0.4-10 \mathrm{~Hz})$ & Pre. freq $(\mathrm{Hz})$ \\
\hline T01 & 40.95818 & 27.49630 & 1 & 0.047 & rf & $16-2$ & 349 & $\mathrm{D}$ & 3.1 & 3.6 \\
\hline T02 & 40.98201 & 27.54817 & 65 & 0.05 & $c$ & $16-2$ & 334 & $\mathrm{D}$ & 3.1 & 3.5 \\
\hline T03 & 40.99014 & 27.53412 & 148 & 0.005 & s & $24-3$ & 359 & C & 3.0 & 9.5 \\
\hline T04 & 40.97891 & 27.51511 & 30 & 0.072 & rf & $20-2.5$ & 458 & C & 2.6 & 13.5 \\
\hline T05 & 40.98146 & 27.48625 & 42 & 0.04 & $\mathrm{al}$ & $20-2.5$ & 427 & C & 3.1 & 9.5 \\
\hline T06 & 40.99851 & 27.50511 & 160 & 0.052 & CS & $20-2.5$ & 380 & C & 3.1 & 11.0 \\
\hline T07 & 40.97585 & 27.51673 & 3 & 0.039 & rf & $16-2$ & 326 & $\mathrm{D}$ & 3.4 & 8.3 \\
\hline T08 & 40.96151 & 27.48737 & 17 & 0.082 & $c$ & $20-2.5$ & 414 & C & 2.7 & 12.6 \\
\hline T09 & 40.97543 & 27.50028 & 52 & 0.088 & sa & $20-2.5$ & 413 & $C$ & 2.8 & 9.2 \\
\hline T10 & 40.99137 & 27.55834 & 38 & 0.047 & s & $20-2.5$ & 311 & $\mathrm{D}$ & 3.4 & 5.9 \\
\hline T11 & 40.99297 & 27.58932 & 66 & 0.068 & CS & $16-2$ & 298 & D & 3.3 & 3.2 \\
\hline T12 & 40.98678 & 27.57682 & 4 & 0.015 & al & $20-2.5$ & 334 & $\mathrm{D}$ & 3.5 & 4.8 \\
\hline T13 & 40.98077 & 27.55812 & 8 & 0.068 & al & $20-2.5$ & 325 & $\mathrm{D}$ & 3.4 & 5.3 \\
\hline T14 & 40.99173 & 27.97571 & 25 & 0.045 & $\mathrm{cr}$ & $20-2.5$ & 472 & $C$ & 2.7 & 14.5 \\
\hline T15 & 40.97365 & 27.94926 & 5 & 0.019 & $\mathrm{Cr}$ & $16-2$ & 423 & $C$ & 3.0 & 6.1 \\
\hline T16 & 41.01641 & 27.70498 & 67 & 0.034 & $\mathrm{cr}$ & $24-3$ & 532 & $C$ & 2.5 & 13.5 \\
\hline T17 & 40.99273 & 27.84108 & 2 & 0.017 & $\mathrm{Cr}$ & $24-3$ & 548 & C & 2.5 & 7.8 \\
\hline T18 & 41.00319 & 27.67659 & 1 & 0.025 & $\mathrm{al}$ & $20-2.5$ & 375 & $C$ & 3.1 & 9.9 \\
\hline T19 & 40.99074 & 27.61347 & 2 & 0.021 & al & $20-2.5$ & 171 & $E$ & 3.7 & 1.6 \\
\hline T20 & 40.97435 & 27.48372 & 21 & 0.015 & al & $20-2.5$ & 246 & D & 3.5 & 2.3 \\
\hline T21 & 40.96864 & 27.49088 & 50 & 0.11 & s & $16-2$ & 436 & C & 2.9 & 8.6 \\
\hline T22 & 40.95984 & 27.48182 & 11 & 0.018 & $\mathrm{al}$ & $24-3$ & 142 & $E$ & 3.6 & 1.0 \\
\hline T23 & 41.00021 & 27.4931 & 64 & 0.098 & sa & $24-3$ & 428 & C & 2.9 & 8.6 \\
\hline T24 & 40.99142 & 27.48049 & 46 & 0.085 & $c$ & $20-2.5$ & 531 & C & 2.5 & 9.5 \\
\hline T25 & 40.99289 & 27.51033 & 125 & 0.123 & s & $24-3$ & 492 & C & 2.7 & 6.1 \\
\hline T26 & 41.00811 & 27.52728 & 158 & 0.041 & CS & $32-4$ & 478 & $C$ & 2.8 & 14.5 \\
\hline T27 & 40.99369 & 27.56093 & 60 & 0.046 & CS & $20-2.5$ & 502 & C & 2.6 & 13.5 \\
\hline T28 & 40.98784 & 27.57605 & 5 & 0.023 & al & $24-3$ & 232 & D & 3.8 & 2.4 \\
\hline T29 & 40.99193 & 27.57971 & 19 & 0.053 & sa & $24-3$ & 407 & $C$ & 3.1 & 7.0 \\
\hline T31 & 40.99018 & 27.60365 & 31 & 0.039 & $c$ & $24-3$ & 408 & C & 3.0 & 6.8 \\
\hline T32 & 40.99212 & 27.62683 & 11 & 0.112 & sa & $32-4$ & 579 & C & 2.3 & 5.3 \\
\hline T33 & 40.99960 & 27.65805 & 13 & 0.028 & s & $24-3$ & 506 & C & 3.2 & 5.5 \\
\hline T37 & 40.98072 & 27.86725 & 12 & 0.018 & $\mathrm{cr}$ & $20-2.5$ & 519 & $C$ & 2.6 & 7.5 \\
\hline T38 & 40.97327 & 27.93165 & 2 & 0.013 & $\mathrm{Cr}$ & $24-3$ & 240 & $\mathrm{D}$ & 3.8 & 2.0 \\
\hline T39 & 40.99020 & 27.98078 & 27 & 0.261 & $\mathrm{Cr}$ & $20-2.5$ & 779 & B & 2.0 & 15.5 \\
\hline T40-1 & 41.17132 & 27.49647 & 82 & 0.011 & $\mathrm{Cr}$ & $16-2$ & 366 & C & 3.1 & 6.8 \\
\hline T40-2 & 41.17100 & 27.49605 & 82 & 0.011 & $\mathrm{Cr}$ & $24-3$ & 490 & $C$ & 3.0 & 10.2 \\
\hline TEK41 & 41.17580 & 27.50609 & 91 & 0.014 & $\mathrm{Cr}$ & $24-3$ & 392 & C & 3.0 & 4.6 \\
\hline TEK42 & 41.16692 & 27.50545 & 83 & 0.009 & $\mathrm{cr}$ & $20-2.5$ & 349 & $\mathrm{D}$ & 3.3 & 5.3 \\
\hline TEK43 & 41.16063 & 27.79163 & 163 & 0.034 & $\mathrm{Cr}$ & $20-2.5$ & 542 & C & 3.0 & 11.7 \\
\hline TEK44 & 41.15412 & 27.85065 & 194 & 0.024 & $\mathrm{Cr}$ & $24-3$ & 449 & $C$ & 2.8 & 5.1 \\
\hline
\end{tabular}


Table 1 Station code, latitude, longitude, elevation, average slope, surface geology index (GI), array sizes of microtremor measurements, AVs30 values, and NEHRP site class (Continued)

\begin{tabular}{lllllllllll}
\hline TEK45 & 41.18496 & 27.76556 & 125 & 0.031 & $\mathrm{cr}$ & $20-2.5$ & 477 & $\mathrm{C}$ & 10.2 & 2.9 \\
TEK46 & 40.74766 & 27.32757 & 30 & 0.208 & $\mathrm{cr}$ & $16-2$ & 580 & $\mathrm{C}$ & 2.7 & 15.5 \\
TEK47 & 40.61610 & 27.12281 & 11 & 0.012 & $\mathrm{cr}$ & $12-1.5$ & 222 & $\mathrm{D}$ & 3.4 \\
\hline
\end{tabular}

The average site amplification for a frequency range 0.4 to $10 \mathrm{~Hz}$ and fundamental site predominant frequency (Hz) obtained from the theoretical amplification factors Geology index (Gl): al: Alluvium, c: Claystone, sa: Sandstone, s: Siltstone, cs: Clay Sand, rf: Recent Fill, cr: Continental Clastic Rocks units in Fig. 1b

T02, T08, and T31 had similar phase velocities at high frequency. T02 and T31 had the same velocities at low frequencies, while T08, located on the border of alluvium unit, had lower phase velocity. T24 had high velocities at all frequencies because it was located on a hill while the other sites in the group were located on a lowland area.

The sites measured on sandstone were designated group $d$. Their observed phase velocities ranged from 225 to $750 \mathrm{~m} / \mathrm{s}$ at frequencies between 2.5 and $30 \mathrm{~Hz}$. The three sites had consistent dispersion curves except T32. The T32 site showed a very high phase velocity $(>500 \mathrm{~m} / \mathrm{s})$ at high frequencies.

The sites in groups $e$ and $f$ were deployed on Oligocene siltstone and Miocene clay-sandstone units, respectively. The dispersive features of both groups were similar, with phase velocities between 180 and $750 \mathrm{~m} / \mathrm{s}$ on average. The geological unit of group $f$ is younger than group e, with the former located in the northern part of the city center. T03 and T25, with higher velocities at high frequencies, were located at a high elevation

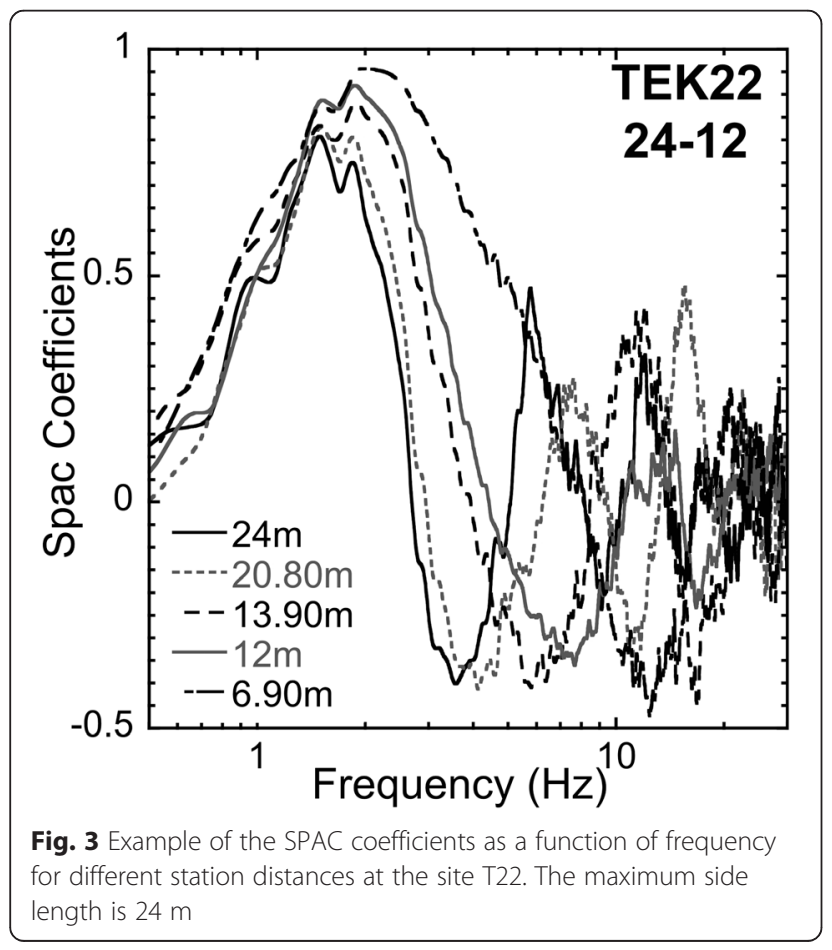

$(\sim 150 \mathrm{~m})$ with respect to the other sites in group e. In group $f$, T27 had a high phase velocity at high frequency like T25.

There were four and three observation sites in Muratli and Corlu towns, respectively, in group $g$. The phase velocities were between 210 and $630 \mathrm{~m} / \mathrm{s}$ at frequencies between 3 and $30 \mathrm{~Hz}$. Both towns are located in a flat area, and there is no significant elevation difference in Muratli. T44 was located at the highest elevation $(\sim 200 \mathrm{~m})$ among the other sites in Corlu. It had a high velocity at a high frequency. On the other hand, the Corlu River, which built Quaternary alluvial beds, cuts both towns. The similar dispersion curves may reflect the similar geological and geomorphologic structures.

There were 6 sites in Marmara Ereglisi (group h). The observed phase velocities showed a wide variation from 160 to $850 \mathrm{~m} / \mathrm{s}$ at frequencies between 4 and $30 \mathrm{~Hz}$. Site T39 showed a very high velocity $(650-900 \mathrm{~m} / \mathrm{s})$. The dispersion curve of T38 was very similar to those sites located on alluvial areas.

\section{Inversion of phase velocities from dispersion curves}

The observed phase velocities were used for an estimation of $1 \mathrm{D} \mathrm{S}$-wave velocity structure profiles. We used a hybrid heuristic method (Yamanaka 2007) as an inversion method to find an optimal $\mathrm{S}$-wave velocity model. This method searches a 1D soil profile by minimizing the misfit function that is defined as a sum of squared differences between the observed and calculated phase velocities. The misfit function, $E$, can be expressed by

$$
E_{i}=\frac{1}{N} \sum_{i=1}^{N}\left[v_{i}^{o}-v_{i}^{c}\right]^{2}
$$

where $v_{i}^{o}$ and $v_{i}^{c}$ are the observed and calculated phase velocities of the Rayleigh wave, respectively, and $N$ is the number of data. The method used for theoretical dispersion curves of the fundamental mode of Rayleigh waves is based on Haskell (1953). We assumed a horizontally layered, isotropic, and homogenous model. The layer model is characterized by four parameters: thickness $(h)$, density $(\rho)$, P-wave velocity $(V p)$, and S-wave velocity $(V s)$ for each layer. Thicknesses and shear-wave velocities are the unknown parameters in the inversion. The density 

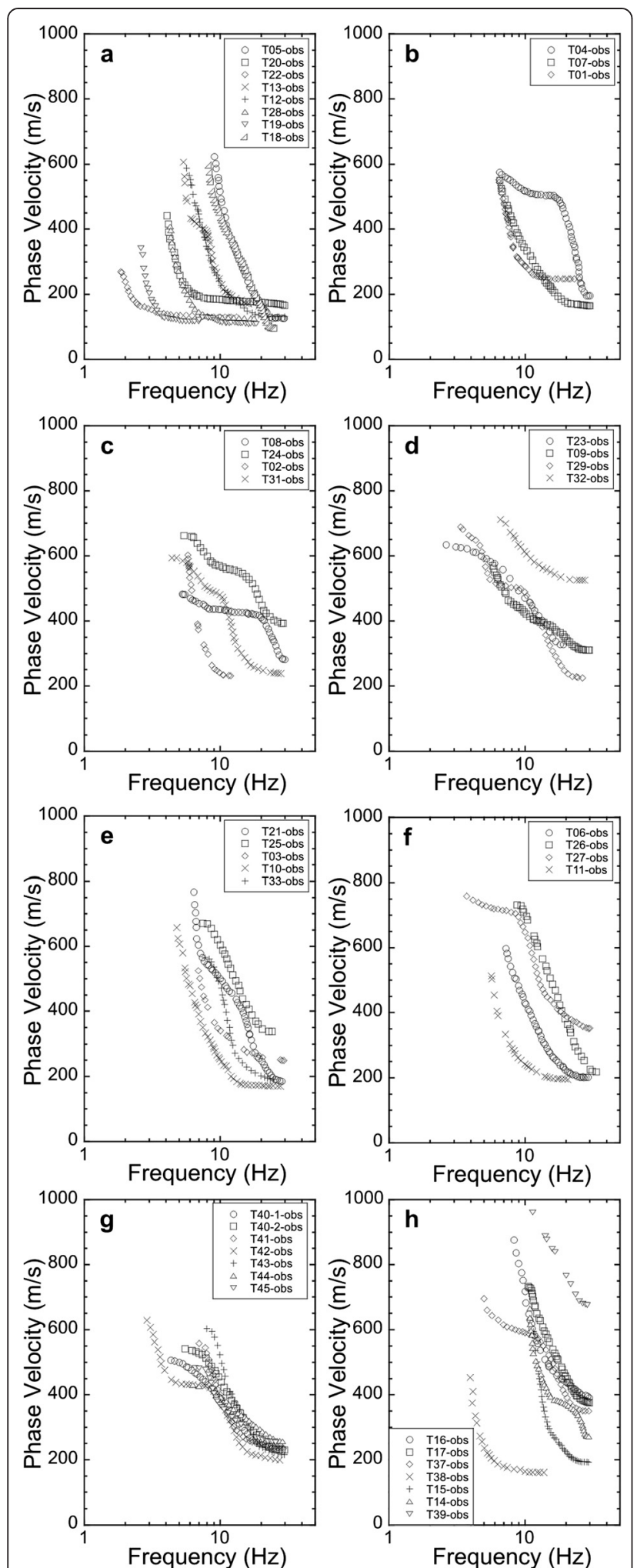

Fig. 4 Observed Rayleigh wave phase velocities dispersion curves of 42 sites in Tekirdag obtained by the SPAC method. The sites are grouped according to their geological units: a alluvial, $\mathbf{b}$ resent landfill, c claystone, $\mathbf{d}$ sandstone, e siltstone, $\mathbf{f}$ clay-sand stone, continental clastic rocks, carbonates, Muratli, Corlu (g), and Marmara Ereglisi (h) values were given as $1.7,1.9$, and $2.1 \mathrm{gr} / \mathrm{cm}^{3}$ for the layer model. P-wave velocity is not inverted but derived from $\mathrm{S}$-wave velocity by using the empirical relation by Kitsunezaki et al. (1990), defined as

$$
V p=1.29+1.11 * V s
$$

where the units of $V p$ and $V s$ are expressed in kilometer/ second.

We generally used two or three layers in the inversion. We applied 50 inversions with 100 generations using different seeds of random number generators, such that a good model with smaller misfit survives to a greater extent in the next generation, while bad models are replaced by newly generated models (Yamanaka and Ishida 1996; Yamanaka 2007). The final model was selected as an acceptable solution if its average misfit was less than 10 \% (Lomax and Snieder 1994). Appropriate search limits were decided after several trial runs of the inversion algorithm. We used narrow search limits for some sites for an easy convergence of the misfit. We had difficulties finding common search limits for the observed data at all sites. Table 2 shows the lower and upper search limits of the unknown parameters and an optimal final model for three selected sites as examples. Figure 5 shows examples for the comparison between the observed and inverted phase velocities, and Fig. 6 shows 1D S-wave profiles for each group given in Fig. 4. We found good fits between the observed and calculated velocities for all sites. It is clear that our final models represent the observed data well at most frequencies.

\section{Results}

Interpretation of the 1D S-wave velocity structure profiles The $V s$ profiles of the sites in group a clearly indicate the variation in thickness of the alluvial sediments (Fig. 6a). The inversion results show that Cevizli Creek

Table 2 Example of search limits and optimal final models for the sites T22, T33, and T41

\begin{tabular}{lllll}
\hline Sites & Search limits & & \multicolumn{2}{l}{ Final optimal model } \\
\hline T22 & Vs $(\mathrm{m} / \mathrm{s})$ & $\mathrm{H}(\mathrm{m})$ & Vs $(\mathrm{m} / \mathrm{s})$ & $\mathrm{H}(\mathrm{m})$ \\
& $100-200$ & $5-50$ & 142 & 32 \\
& $200-500$ & $10-20$ & 349 & - \\
T33 & $100-200$ & $5-10$ & 182 & 6 \\
& $200-600$ & $10-50$ & 442 & 15 \\
& $600-800$ & - & 708 & - \\
T41 & $200-300$ & $6-10$ & 248 & 7 \\
& $300-400$ & $10-80$ & 378 & 12 \\
& $500-800$ & - & 665 & - \\
\hline
\end{tabular}



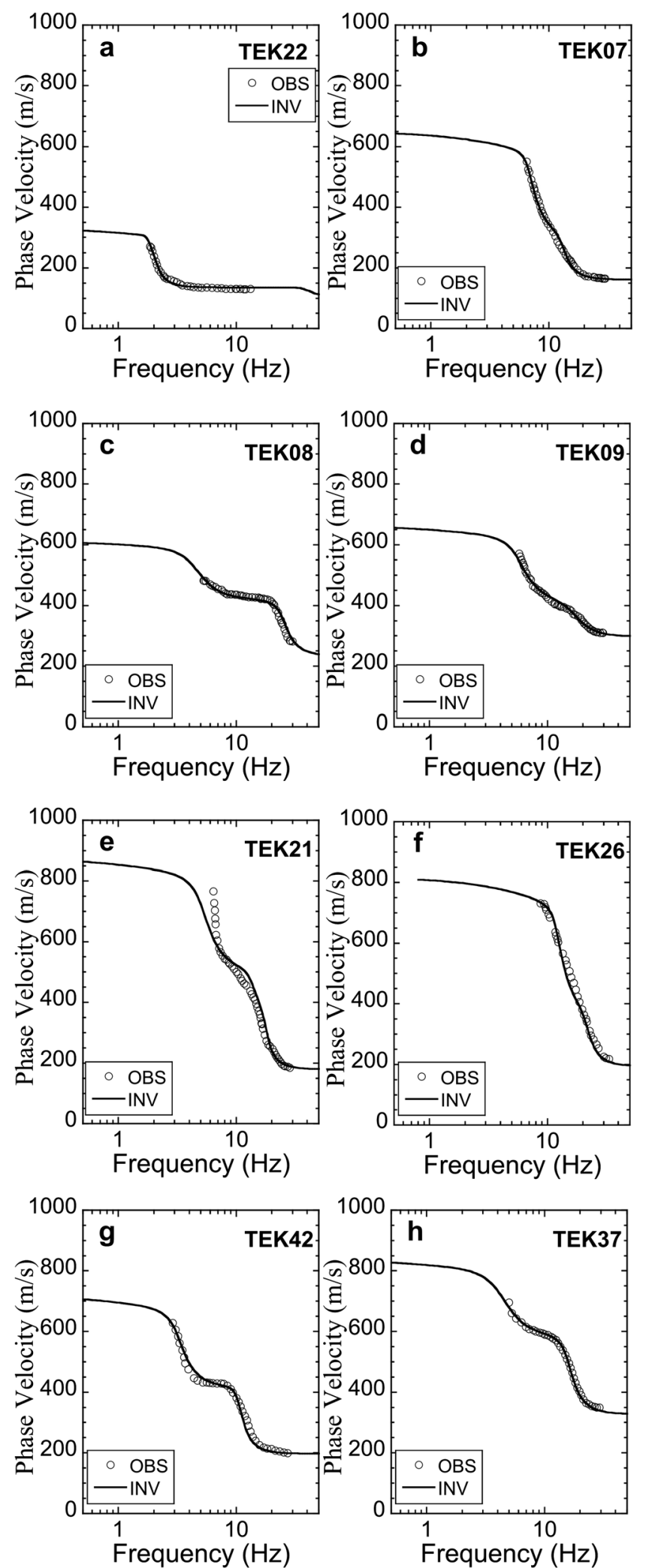

Fig. 5 Example comparison between the observed (open circle) and calculated (solid line) phase velocities from each group (a-h) given in Fig. 4 

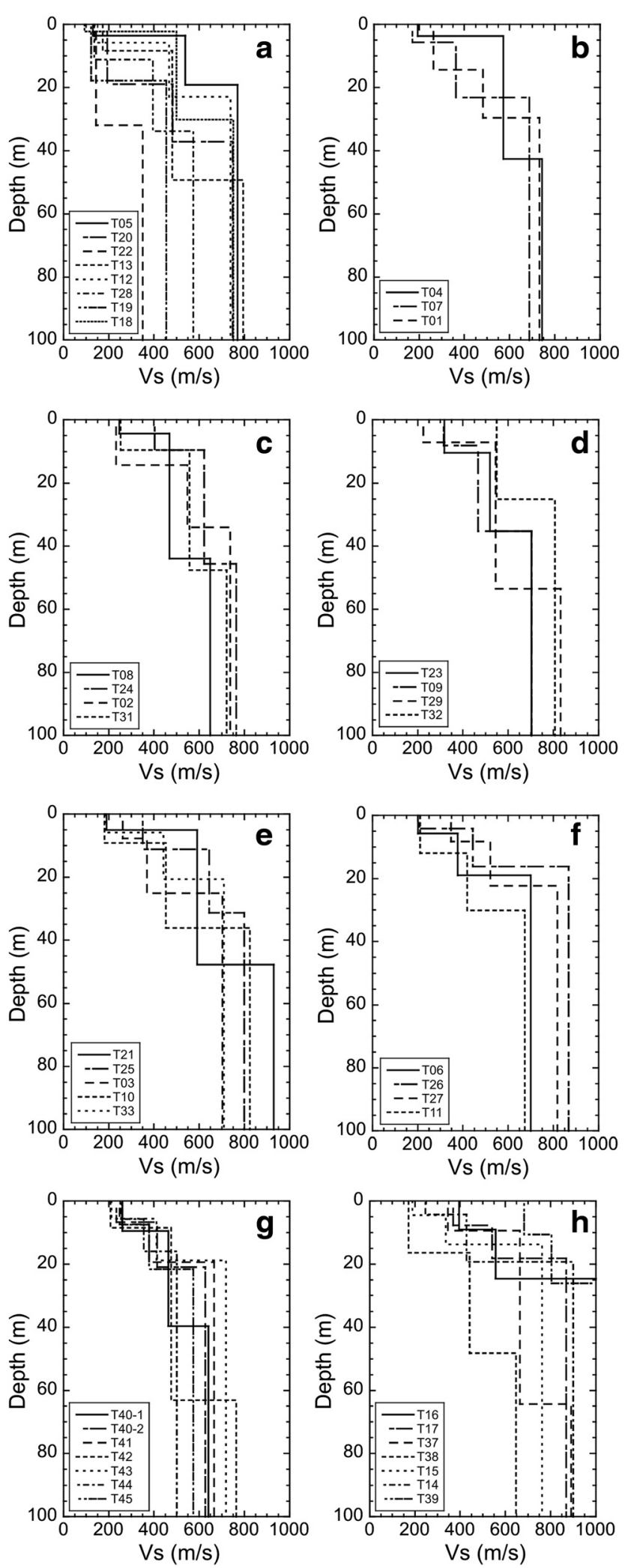

Fig. 6 Comparison of the Vs profile derived from GASA inversion method for each group (a-h) given in Fig. 4 
Table 3 The four-layer model according to average S-wave velocities from the inversion results in Tekirdag

\begin{tabular}{lll}
\hline Layer & Thickness range $(\mathrm{m})$ & Average Vs $(\mathrm{m} / \mathrm{s})$ \\
\hline 1st & $2-32$ & 210 \\
2nd & $8-55$ & 415 \\
3rd & $11-55$ & 600 \\
Engineering bedrock & - & 780 \\
\hline
\end{tabular}

(west of Tekirdag city center) has much thick alluvial sediment $(V s=\sim 140 \mathrm{~m} / \mathrm{s})$ at its mouth $(\sim 30 \mathrm{~m})$ with respect to up river parts $(\sim 20 \mathrm{~m})$. The Agilovası Creek alluvial bed (east of the city center) had the lowest S-wave velocity $(90 \mathrm{~m} / \mathrm{s})$ in the study area. The sites deployed on other alluvial creek beds showed similar velocities in the top layer $(120-140 \mathrm{~m} / \mathrm{s})$. The $\mathrm{S}$-wave velocities of the deepest parts beneath the thick sediments are low $(350-600 \mathrm{~m} / \mathrm{s})$, while the sites on thin sediments have high velocities $(\sim 800 \mathrm{~m} / \mathrm{s})$ as engineering bedrock (T05, T12, T13, T18).

The uppermost layers of sites in groups $b$ to $f$ had an $\mathrm{S}$-wave velocity between 200 and $400 \mathrm{~m} / \mathrm{s}$. These velocities represent the landfill, claystone, sandstone, and siltstone geological units observed on the surface. Distinctively, only one site (T32 in group d) deployed near the seaside had the highest $\mathrm{S}$-wave velocity $(\sim 550 \mathrm{~m} / \mathrm{s})$ for its first layer. The $\mathrm{S}$-wave velocity of the engineering bedrock was between 750 and $930 \mathrm{~m} / \mathrm{s}$. The engineering bedrock was not revealed at T08 and T11 in group $c$ and $f$, respectively.

The Vs profiles in Corlu and Muratli (group g) were highly consistent, especially for shallow layers. The $\mathrm{S}$-wave velocity of the first layers was 210 to $260 \mathrm{~m} / \mathrm{s}$. Only two sites (T42, T43) showed the engineering bedrock $(\sim 740 \mathrm{~m} / \mathrm{s})$ in this group.

The sites in group $h$ in the town of Marmara Ereglisi are located along the coastline. The S-wave velocity of the top layer and the engineering bedrock were 200$370 \mathrm{~m} / \mathrm{s}$ and $760-900 \mathrm{~m} / \mathrm{s}$, respectively. In addition, we estimated the deep structure velocities at two sites at 1050-1200 m/s (T16 and T39).

In general, the $1 \mathrm{D} V s$ profiles indicate that the Tekirdag city center and coastal areas have different $\mathrm{S}$-wave shallow structures. The top layers of the sites located on stiff soil had a velocity of $\sim 200 \mathrm{~m} / \mathrm{s}$. On the contrary, consistent velocity values were observed in Marmara Ereglisi, Muratli, and Corlu towns. The engineering bedrock velocities ranged from 700 to $930 \mathrm{~m} / \mathrm{s}$. The sites in Marmara Ereglisi indicated the highest velocity for the deeper structure. On the other hand, the engineering bedrock beneath the sites in Corlu and Muratlı could not be revealed due to the thick upper soft soil layers in the Thrace Basin. The depth of the engineering bedrock is $20-50 \mathrm{~m}$ in Tekirdag city center and its eastern part and 10$65 \mathrm{~m}$ for Marmara Ereglisi.

Our inversion results indicate that the $\mathrm{S}$-wave profiles can be grouped with four layers for Tekirdag region (Table 3). Thirty-four sites had the first layer velocity $(90<V s<320 \mathrm{~m} / \mathrm{s})$. The highest velocity of the first layer was $\sim 320 \mathrm{~m} / \mathrm{s}$ (T09, T23). Thirty-one sites had the second layer with an S-wave velocity of $320 \leq V s<500 \mathrm{~m} / \mathrm{s}$. T19, T22, and T32 had only two layers. Twenty-five sites contain the third layer with a $V s$ velocity from 500 to $700 \mathrm{~m} / \mathrm{s}$. Twenty-nine sites had the fourth layer with a velocity of $700 \leq V s<930 \mathrm{~m} / \mathrm{s}$. T16 and T39 had high velocities for the deep parts which may be interpreted as the fifth layer.

The average shear-wave velocities of the layers were $210,415,600$, and $780 \mathrm{~m} / \mathrm{s}$ from the top to the bottom. The thicknesses of all layers changed from 2 to $55 \mathrm{~m}$ as tabulated in Table 3.

Figure 7 shows the velocity cross section along the AA' profile in Fig. 1b. The cross section was selected roughly in an east-west direction to identify the velocity

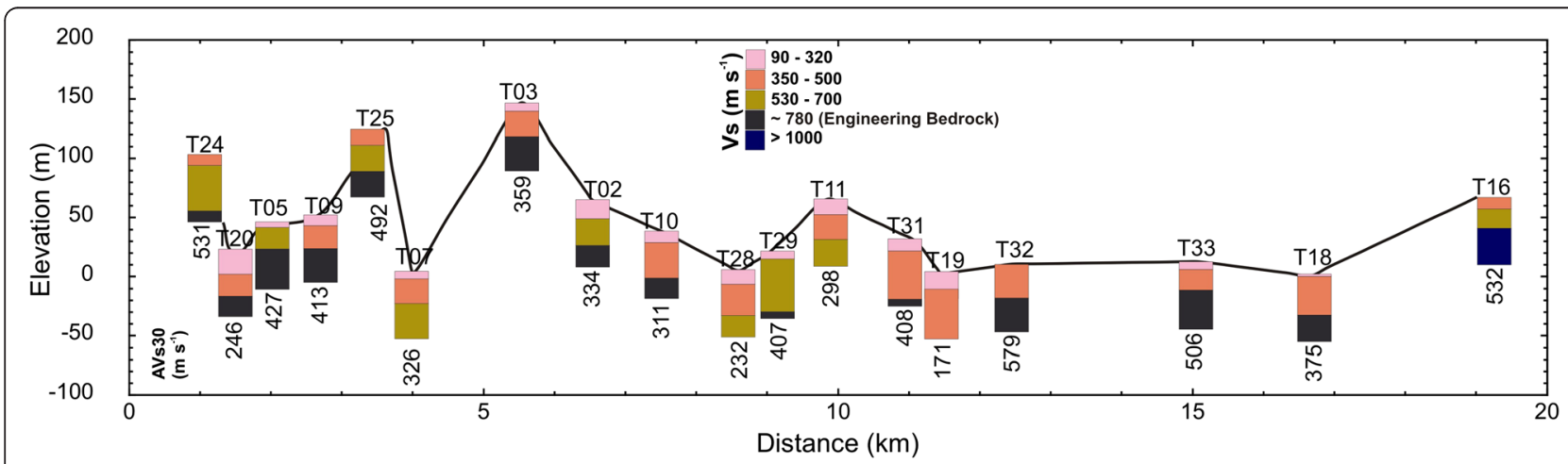

Fig. 7 The AA' profile in Fig. 1b parallel to the coastline of Tekirdag, showing inferred shallow subsurface structures. The average S-wave velocities of the upper $30 \mathrm{~m}$ are given below the layer structures, to show the variation of the soft sediments from south-west to north-east 
variation along the coastline, effects of the topography, and alluvial creek beds. Most of the sites had the first layer with low velocities except for T24, T25, T32, and T16. These sites were generally located on lowland areas covered by alluvial sediments (i.e., T20, T19, and T28). The sites on the top of hills had thin or no low velocity layers (i.e., T03, T25). It is clear that the high velocity layers are dominant at sites along the eastern coastline of Tekirdag (T32, T33). The engineering bedrock $(V s \sim 780 \mathrm{~m} / \mathrm{s})$ cannot be observed in the first $30 \mathrm{~m}$ from the surface (T07, T28, T11, T19). We could not determine the velocity in the engineering bedrock at sites on the alluvial basin because of the thick first and second layers. Distinctively, T16 has a high velocity layer at the bottom $(V s>1000 \mathrm{~m} / \mathrm{s})$.

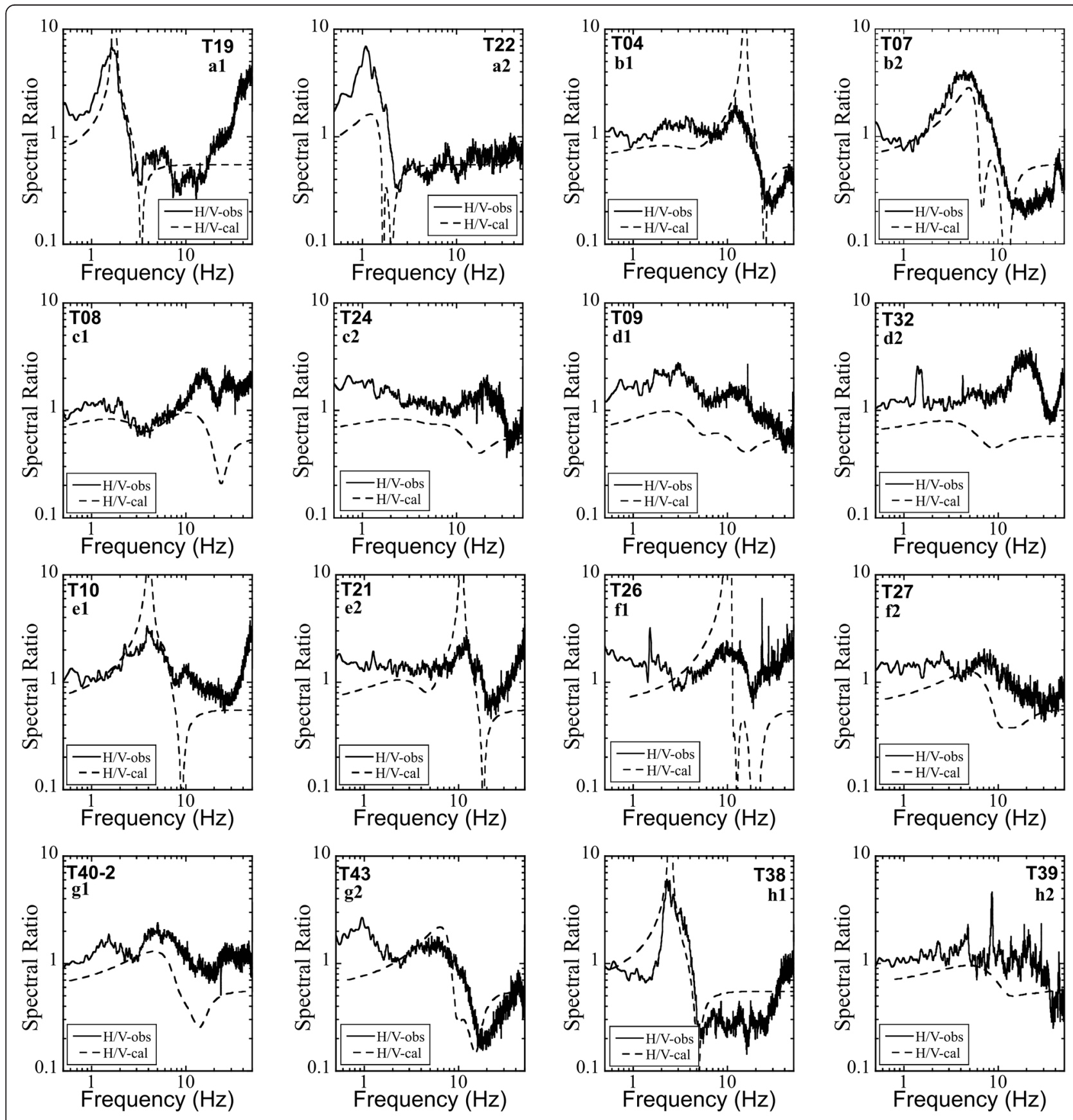

Fig. 8 Spectral ratio of the observed microtremor data (solid line) with computed HN of the fundamental mode Rayleigh waves (dashed lines) for selected sites from each group (a-h) given in Fig. 4 


\section{Horizontal-to-vertical spectral ratios}

The spectral ratios between the horizontal and vertical components of the observed microtremor data were compared with the computed ellipticity of fundamental mode Rayleigh waves for the inverted 1D soil profiles in Fig. 6. Our aim for the comparison was to confirm the appropriateness of the inversion. Comparisons for two selected sites from each group $(a-h)$ are shown in Fig. 8. We followed the steps described by Zaineh et al. (2012) for the spectral ratio calculation. The Fourier amplitude spectra were calculated using $81.92 \mathrm{~s}$ time segments and then smoothed using the Parzen window with a bandwidth of $0.1 \mathrm{~Hz}$

Generally the sites that had a thin first layer with low velocities exhibited a dominant peak at high frequencies $(\sim 10 \mathrm{~Hz})$ due to high velocity contrast (i.e., T04, T21, T26). On the other hand, we observed peak values at low frequencies $(\sim 1-3 \mathrm{~Hz})$ for much thicker first layers with low velocities $(\sim 150 \mathrm{~m} / \mathrm{s})$ (i.e., alluvial at T19, T22, T38). The sites with no significant velocity contrast between the layers had almost flat characteristics in the frequency range of $0.4-10 \mathrm{~Hz}$ (i.e., T24, T27, T32, and T39). The sites in Muratlı and Corlu town had similar flat characteristics at a frequency up to $\sim 6 \mathrm{~Hz}$ (T40-2, T43).

Comparison between the observed and calculated H/V ratios shows that the observed peak frequency characteristics are in good agreement with the ellipticity at frequencies between 1 and $20 \mathrm{~Hz}$. We compared all the observed and calculated peak frequencies of the H/Vs in logarithmic graphs as shown in Fig. 9.

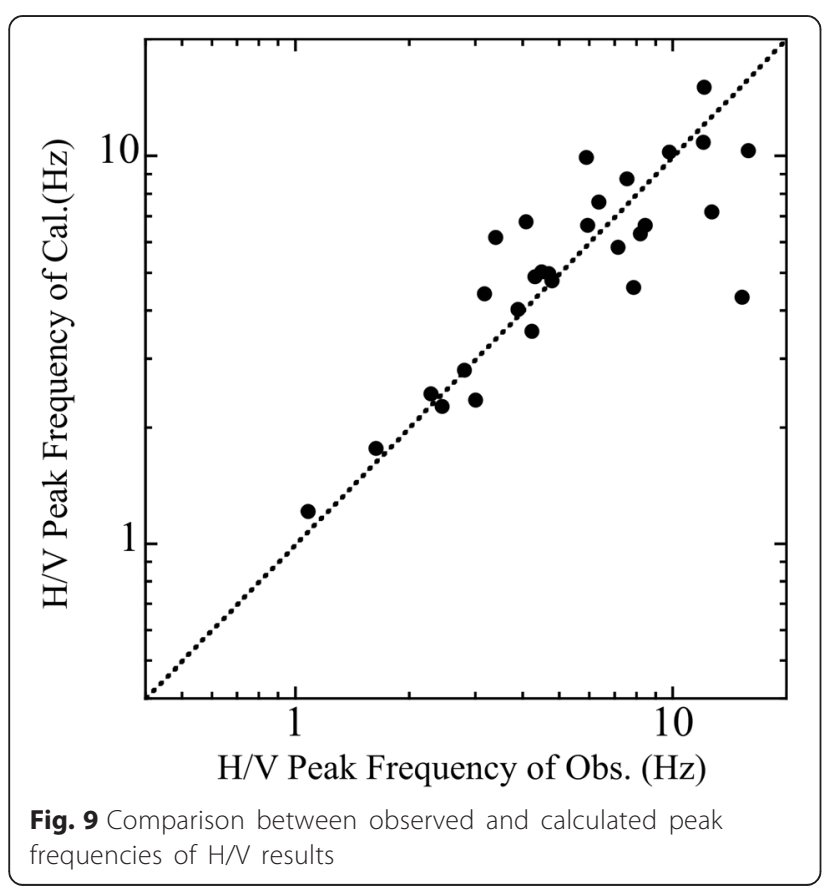

\section{AVs30 distribution}

The average shear-wave velocity values for the upper most $30 \mathrm{~m}$ (AVs30) were calculated according to the following CEN (2004) equation,

$$
\mathrm{AVs}_{30}=\frac{30}{\sum_{i=1}^{N} \frac{h_{i}}{V_{i}}}
$$

where $h_{i}$ and $V_{i}$ denote the thickness (in meters) and the shear-wave velocity of the $i$-th layer, in a total of $N$, existing in the top $30 \mathrm{~m}$. The AVs30 histogram is given in Fig. 10 and indicates a normal distribution with an average value of $410 \mathrm{~m} / \mathrm{s}$. AVs30 for most of the sites were distributed from 300 to $500 \mathrm{~m} / \mathrm{s}$.

The average AVs30 values along the AA' profile are shown in Fig. 7. While the AVs30 values were higher in the west and the north $(\sim 530 \mathrm{~m} / \mathrm{s})$, they decreased in the city center. However, the AVs30 increased for sites to the east of T28. Low values were observed at sites having thick low velocity stiff soil layers (i.e., T11, T19, T29).

According to the National Earthquake Hazards Reduction Program (NEHRP) site classification (A-E), 2 sites are on soft soil (E), 11 sites on stiff soil (D), 28 sites on very dense soil/soft rock $(C)$, and 1 site on rock (B) (Table 1). The sites in the northern part of the city center and the east part along the coastline are on soft rock (C). Marmara Ereglisi is also located on the soft rock except for T39 and T38 that are on rock (B) and stiff soil (D), respectively. The sites T01, T07, T12, and T13 close to the sea are on stiff soil (D). T20 and T28 were also located on the alluvial creek bed and are

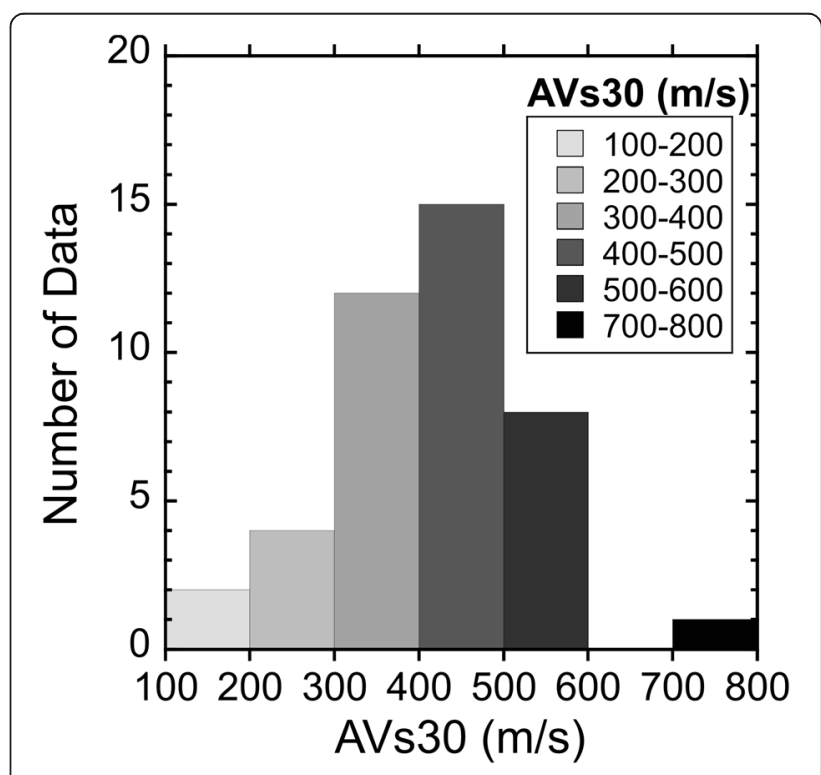

Fig. 10 The AVs30 distribution of Tekirdag 
classified as stiff soil (D). However, at T02, T10, and T11 located in stone units, the AVs30 was around $310 \mathrm{~m} / \mathrm{s}$ (stiff soil). Although the sites located near the seaside in Tekirdag showed low AVs30 values (E-D), we found high values (C-B) in Marmara Ereglisi (Fig. 13a). T38 had a similarly low value $(240 \mathrm{~m} / \mathrm{s})$ at an alluvial site. The AVs30 velocities in Corlu (C) were higher than Muratlı (D). The only site in Muratli, T42, is on soft rock $(490 \mathrm{~m} / \mathrm{s})$. It is located on the border between alluvial and continental clastic rocks and carbonates units.

\section{Discussion}

\section{D site amplification factors}

Site amplification factors were computed to understand the seismic motion behavior on the different geological units in the study area. Since we determined the depth to the engineering bedrock at 29 sites, we used a common half-space layer for each site as the engineering bedrock with an average $V s$ of $\sim 780 \mathrm{~m} / \mathrm{s}$. We did not observed engineering bedrock beneath the other 13 sites. We used the average engineering bedrock depth of neighboring sites in the amplification calculations for those sites.

We used 1D wave propagation theory for vertically propagating $\mathrm{S}$-waves to calculate site amplification. The amplification factor defines the ground motion on the surface to that of incident wave from the engineering bedrock. Because of lack of the quality factor information $(Q)$ for Tekirdag and surroundings, it was assumed to be constant at $1 / 15$ of $V s(Q=V s / 15)$ in this study (Iida et al. 2005).
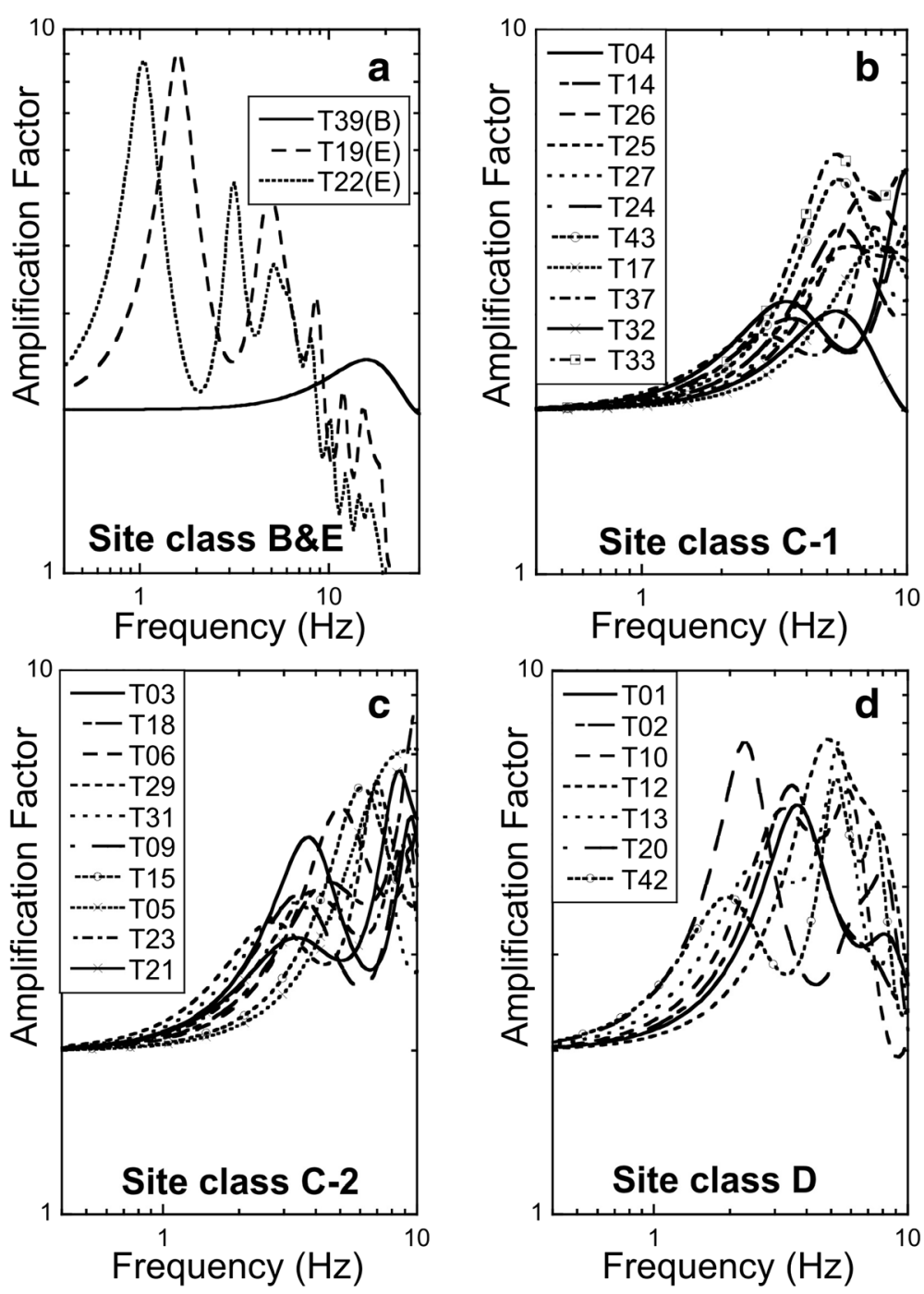

Fig. 11 Comparison of the theoretical amplification for 32 sites according the NEHRP site classifications. a site class B and E, b-c site class $\mathrm{C}, \mathrm{d}$ site class D. The amplification values are computed using 1D transfer functions for vertically incident SH waves. The engineering bedrock S-wave velocity is $V_{s}=780 \mathrm{~m} / \mathrm{s}$. The $Q$ value is assumed to be $1 / 15$ of Vs $(Q=V s / 15)$. Site class $C$ divided into two subgroups according to velocity ranges C1, $450<\mathrm{AVs} 30<600 \mathrm{~m} / \mathrm{s}$ and $\mathrm{C} 2,350<\mathrm{AVs} 30<450 \mathrm{~m} / \mathrm{s}$ 
Figure 11 shows the theoretical amplification factors for the 31 sites according to the NEHRP classification. There was only 1 site T39 on B class (rock) with a predominant frequency of $15.5 \mathrm{~Hz}$ and an amplification value of 2. T22 was located in the Cevizli River with a sediment layer thickness of $32 \mathrm{~m}$. T19 was located in Gazioglu Creek with a low velocity $(120 \mathrm{~m} / \mathrm{s})$ thick first layer. We could not detect the engineering bedrock at these sites. T19 and T22 in E class had predominant frequencies of 1.6 and $1.0 \mathrm{~Hz}$, respectively, with similar amplifications of $\sim 9$.

The sites in class $\mathrm{C}$ were divided into two subgroups according to their AVs30 velocity ranges: C-1 for 450$650 \mathrm{~m} / \mathrm{s}$ and C-2 for $350-450 \mathrm{~m} / \mathrm{s}$. Eleven sites in C-1 showed that the predominant frequencies ranged from $5 \mathrm{~Hz}$ to $15 \mathrm{~Hz}$. The minimum amplification in the group was approximately 4 , while the maximum amplification ( 6.5) observed at T04 at a frequency of $13.5 \mathrm{~Hz}$ was similar at T27, both these sites being located on the youngest geological units. T14 had similar properties to T04 but the maximum frequency was 14.5 Hz, the same as T26. Although the predominant frequencies were similar $(\sim 5 \mathrm{~Hz})$, amplification at T32 was half that at T33. The effect of the low velocity $(\sim 180 \mathrm{~m} / \mathrm{s})$ layer on the amplification at site T33 is clear.

C-2 contained 10 sites having dominant frequencies between 6 and $11 \mathrm{~Hz}$. The minimum predominant frequency $(\sim 6 \mathrm{~Hz})$ in the group was observed at site T15 located in the downtown of Marmara Ereglisi. T18 shows maximum amplification $(\sim 9)$ at $10 \mathrm{~Hz}$ due to a $2-\mathrm{m}$ thin first layer and very low $\mathrm{S}$-wave velocity $(\sim 90 \mathrm{~m} / \mathrm{s})$ of the alluvial material. We found that the predominant frequencies range for all sites in NEHRP class $\mathrm{C}$ were $5-15 \mathrm{~Hz}$, and the amplification values were observed to be between 3 and 9 .

The sites in class D according to their AVs30 values (250-350 m/s) showed predominant frequencies between 2 and $6 \mathrm{~Hz}$. The most significant amplification was found at T20 located on the alluvial of Cevizli Creek, with a minimum frequency of $2.3 \mathrm{~Hz}$ and an amplification factor of 7. A thick sediment layer affects both the frequency and amplification properties at this site. T12 and T13 also showed the same amplification values at $\sim 5 \mathrm{~Hz}$ as at T20.

T02 had very similar velocity structure to T04. Both sites were located in crowded urban areas and indicated the same amplification $(\sim 6.5)$ with different predominant frequencies. While T04 had a peak value at $13.5 \mathrm{~Hz}, \mathrm{~T} 02$ had a frequency of $3.5 \mathrm{~Hz}$ due to the much thicker $(17 \mathrm{~m})$ first layer. On the other hand, T01 has the same predominant frequency as T02. It is clear from the results that the thickness and velocity of the first layer significantly affect site amplification.

\section{AVs30 and site amplification relationship}

We examined the relationship between the amplification factor and AVs30. We used average amplification factors at frequencies between 0.4 and $10 \mathrm{~Hz}$ (Fig. 12). We found a good correlation between AVs30s and amplification values using a linear regression. Average amplifications on the alluvial sites showed slightly higher values than those predicted from the regression line. On the other hand, the value at a site on sandstone (T32) had smaller amplification than the empiric equation in general.

The alluvial units had higher amplification values than that of the other geological units. Sandstone sites designated as a soft rock (C) and rock sites (B) according to NEHRP showed the lowest amplification value with high AVs30 (T32 and T39) among the all site (Fig. 12).

\section{AVs30 and slope relationship}

The average $\mathrm{S}$-wave velocity in the upper $30 \mathrm{~m}$ is one of the principle parameters for further studies such as microzonation, ground motion prediction equations (GMPEs) etc. (i.e., Stewart et al. 2012). Recent studies have shown good correlation between AVs30 and the slope of topography (e.g., Matsuoka et al. 2006; Allen and Wald 2007; Lemoine et al. 2012; Stewart et al. 2012).

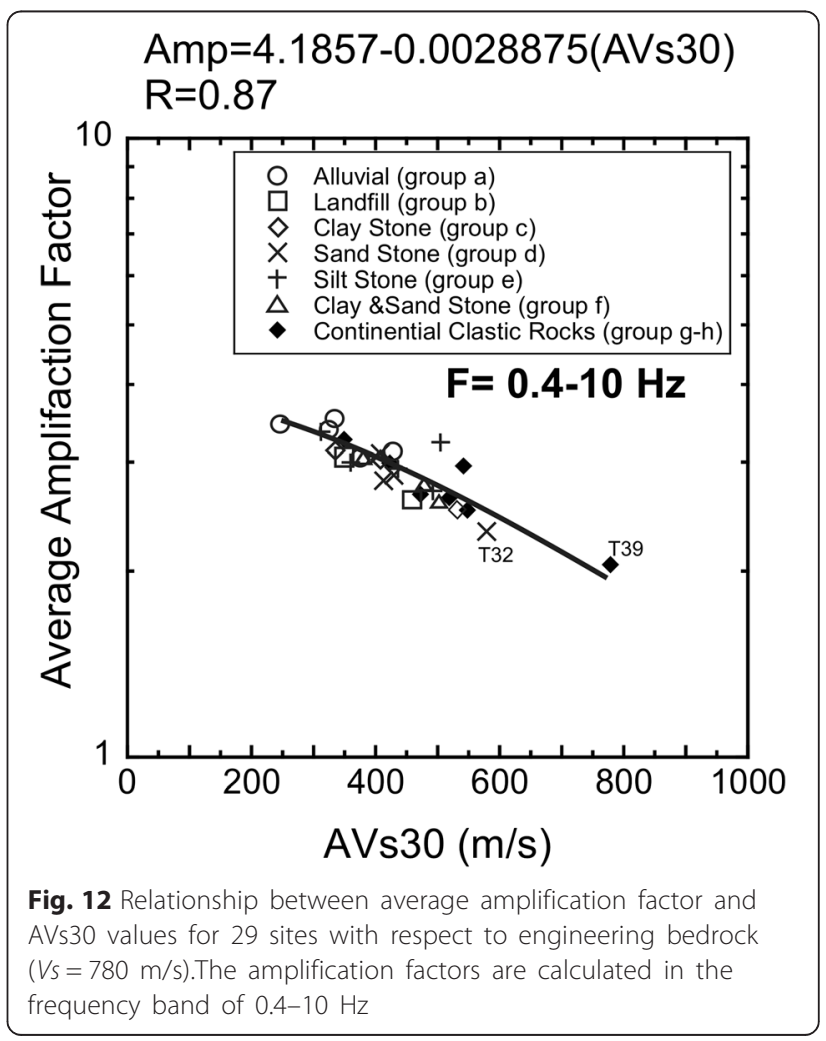


We used the NASA Shuttle Radar Topography Mission (SRTM) 3-s $(90 \mathrm{~m})$ topography data to generate a slope map of Tekirdag and surrounding region. We used Generic Mapping Tools (GMT; Wessel and Smith 1998) routines to analyze the data. First, elevation data was resampled at $30 \mathrm{~m}$ for a smooth transition between the grid points and the derivatives (amplitude of slope). The average slope of each site was calculating using the neighboring grids (in eight directions). Figure 13a shows the slope variation and AVs30 values for the sites in the Tekirdag. Creek beds (alluvial areas) that had low slope and steep hills around the valleys had high slope amplitude. It is clear in Fig. 13a and Table 1 that there is a positive relationship between AVs30 and slope. AVs30 in the city center were between $300-400 \mathrm{~m} / \mathrm{s}$, and in the west part of city center, they were $400-500 \mathrm{~m} / \mathrm{s}$. The maximum velocity was at
T39 in Marmara Ereglisi. The AVs30 and slope values in Muratlı were smaller than that of Corlu (Fig. 13a).

The different geological units are also represented with different symbols according to the NEHRP site class range in Fig. 13b. The sites on alluvial areas indicated low slope and velocities. The landfill areas had much high slope values because they are in the city center that settled on the hills. The sites on the siltstone, sandstone, and claystone units were sparsely distributed. Continental clastic rocks that actually consist of silt/clay/sandstone units as mentioned before showed low average slope values because these units cover the flat areas of Corlu and Muratlı towns. The highest slope values were observed in Marmara Ereglisi. Unlike the other sites, T39 in Marmara Ereglisi had the highest velocity and slope value among the all sites.
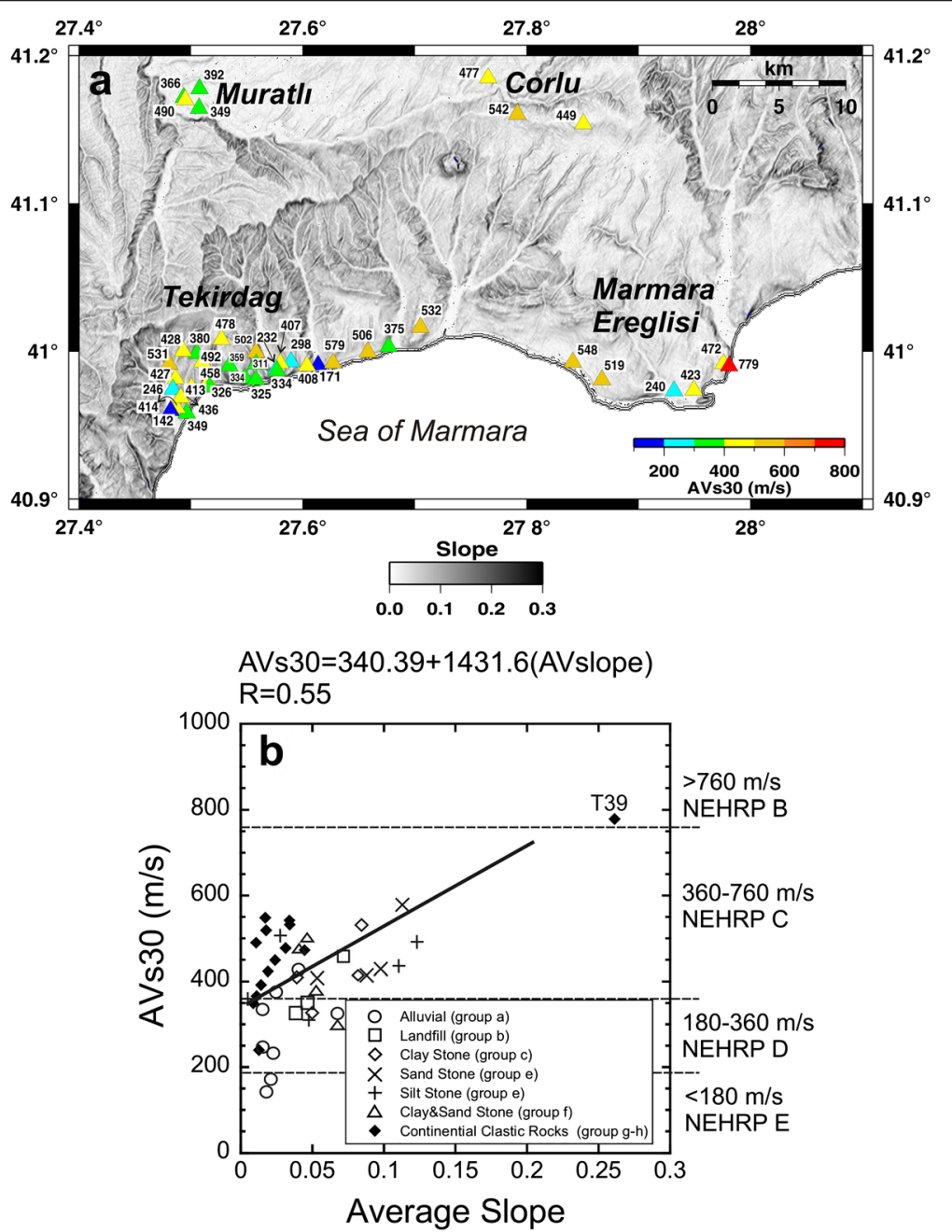

Fig. 13 a AVs30 value of the sites on the slope map of the study area. b Relationship between average slope and AVs30 values for 42 sites. Slope ranges within NEHRP site class 


\section{Comparisons with the previous site effect studies in Marmara region}

The site effect studies in Marmara Region indicated that high amplifications are observed at frequencies less than 4-5 Hz (i.e., Ozel et al. 2002). In particular, the Avcilar and Yesilkoy districts of the Istanbul metropolitan area have amplification between frequencies of 1 and $2 \mathrm{~Hz}$ (Ergin et al. 2004; Bozdag and Kocaoglu 2005). Picozzi et al. (2009) indicated that the southern coastline of the western part of Istanbul has fundamental frequencies as low as $0.1 \mathrm{~Hz}$ (i.e., Avcilar, Bakirkoy district) because of the thick sediments in the area. They found fundamental frequencies of $0.5-1 \mathrm{~Hz}$ for Atakoy and Zeytinburnu. On the other hand, Sørensen et al. (2006) obtained dominant peak amplifications (3-4) at around $1 \mathrm{~Hz}$ from microtremor $\mathrm{H} / \mathrm{V}$ results at 30 sites in Atakoy and its surroundings.

Our results indicate that the dominant frequencies in the Tekirdag region were all higher than earlier results. Only two sites located on the alluvial creek bed showed maximum amplification at less than $2 \mathrm{~Hz}$. Most of the sites located on claystone, sandstone, and siltstone units in Tekirdag had predominant frequencies higher than $2 \mathrm{~Hz}$. The fundamental frequency range in Tekirdag was 1-10 Hz. However, the predominant frequency range was 1-16 Hz. As a result, Tekirdag and surrounding areas show better site responses with respect to the western part of Istanbul.

\section{Conclusions}

This study is the first comprehensive microtremor array measurements in Tekirdag city center and Marmara Ereglisi, Muratll, and Corlu districts. The microtremor array measurements were performed at 44 sites to estimate $\mathrm{S}$-wave velocity structures of the shallow soil layers in the study area. The observed Rayleigh wave phase velocities were between $\sim 90$ and $930 \mathrm{~m} / \mathrm{s}$ in a frequency range from 2 to $30 \mathrm{~Hz}$. We deduced the S-wave structures of the shallow soil in Tekirdag city center and coastal area. The top layers of sites located on the sandstone, claystone, and siltstone units had velocities of $\sim 200 \mathrm{~m} / \mathrm{s}$. The velocities and thickness of the alluvial creek beds in coastal area were also clearly identified. The engineering bedrock velocities in the study area ranged from 700 to $930 \mathrm{~m} / \mathrm{s}$. The most significant part of the study area belongs to the alluvial creek beds. Our results indicate that the observed phase velocities change due to the thickness of alluvium. Additionally, we noticed that the shapes of the observed dispersion curves of alluvial units were similar.

The site amplifications, predominant frequencies, and site classifications according to the AVs30 values were determined to be input for future microzonation studies in Tekirdag and surroundings. According to the NHERP site classification, 28 sites are on dense soil/soft rock (class C) and 11 sites are on stiff soil (class D). We also proposed the relationship equations for AVs30-slope and AVs30-amplification for future use in site response prediction studies.

\section{Competing interests}

The authors declare that they have no competing interest.

\section{Authors' contributions}

OK analyzed, interpreted all data, and wrote the manuscript. OK, KC, SC, OO, $\mathrm{HY}$ and $\mathrm{KH}$ contributed field studies and organized field plans. KC, HY, OO participated the discussions during the data analyzing, contributed to improvement manuscript. All authors read and approved the manuscript.

\section{Acknowledgements}

The authors would like to express deep gratitude to the Japan Ministry of Education, Culture, Sport, Science, and Technology (MEXT) for financial support, Science and Technology Research Partnership for Sustainable Development (SATREPS) for support for one of the authors' PhD education at the Tokyo Institute of Technology. This study is part of the "Earthquake and Tsunami Disaster Mitigation in the Marmara Region and Disaster Education in Turkey (MarDiM)" project, is also supported by Istanbul University (BAP Project no: 44524). The authors also would like to thank Dr. Hussam Eldein Zaineh's help and contribution for this study. The author also would like to thank Assoc. Dr. Aysegul Askan (Middle East Technical University), MSc students Bengi Behiye Aksahin and Safa Arslan (Istanbul University), PhD student Fatma Nurten Sisman Dersan (Middle East Technical University), MSc Kaouro Kojima and MSc Tomohir Tsuchiya (Tokyo Institute of Technology) for their helps during the 2013-2014 field studies.

\section{Author details}

${ }^{1}$ Department of Environmental Science and Technology, Tokyo Institute of Technology, Tokyo, Japan. ²Department of Geophysical Engineering, Çanakkale Onsekiz Mart University, Çanakkale, Turkey. ${ }^{3}$ Earthquake and Tsunami Forecasting System Research Group R\&D Center for Earthquake and Tsunami (CEAT), Japan Agency for Marine-Earth Science and Technology (JAMSTEC), Tokyo, Japan. ${ }^{4}$ Department of Geophysical Engineering, Istanbul University, Istanbul, Turkey. ${ }^{5}$ National Research Institute of Fire and Disaster, 4-35-3 Jindaiji-higashi-machi, Chofu, Tokyo 182-0012, Japan.

Received: 26 March 2015 Accepted: 29 August 2015

Published online: 04 November 2015

\section{References}

Allen TI, Wald DJ (2007) Topographic slope as a proxy for seismic site-conditions (VS30) and amplification around the globe. US Geol Surv 2007-1357:69, Open-File Rept

Ambraseys NN, Finkel CF (1995) The seismicity of Turkey and adjacent areas-a historical review, 1500-1800. M. S. Eren Publications and Books, Istanbul

Asten MW, Askan A, Ekincioglu EE, Sisman FN, Ugurhan B (2014) Site characterization in north-western Turkey based on SPAC and HVSR analysis of microtremor noise. Explor Geophys 45:74-85

Barka A (1992) The North Anatolian fault zone. Annales Tectonicae 6:164-195

Bozdag E, Kocaoglu AH (2005) Estimation of site amplifications from shear-wave velocity profiles in Yesilyurt and Avcilar, Istanbul, by frequency-wavenumber analysis of microtremors. J Seismol 9:87-98

CEN (2004) Eurocode 8- design of structures for earthquake resistance. Part 1: general rules, seismic actions and rules for buildings. European standard EN 1998-1, December 2004. European Committee for Standardizitaion, Brussels

Ergin M, Ozalaybey S, Aktar M, Yalcın MN (2004) Site amplification at Avcılar, Istanbul. Tectonophysics 391:335-346

Gok E and Polat O (2012) Microtremor HVSR study of site effects in Bursa City (Northern Marmara Region, Turkey), earthquake research and analysis-new frontiers in seismology, Dr Sebastiano D'Amico (Ed.), ISBN: 978-953-307-840-3, InTech. http://cdn.intechopen.com/pdfs-wm/ 27143.pdf.

Grutas R, Yamanaka H (2012) Shallow shear-wave velocity profiles and site response characteristics from microtremor array measurements in Metro Manila, the Philippines. Explor Geophys 43:255-266 
Haskell NA (1953) The dispersion of surface waves on multilayered media. Bull Seism Soc Am 43:17-34

lida M, Yamanaka H, Yamada N (2005) Wave field estimated by borehole recordings in the reclaimed zone of Tokyo Bay. Bull Seismol Soc Am 95:1101-1119. doi:10.1785/0120040010

Ketin I (1948) Über die tektonisch-mechanischen Folgerungen aus den großen Anatolischen Erdbeben des letzten Dezennium. Geol Rundschau 36:77-83

Kılıç H, Özener PT, Ansal A, Yılııım M, Özaydın K, Adatepe Ş (2006) Microzonation of Zeytinburnu region with respect to soil amplification: a case study. Eng Geol 86:238-255

Kitsunezaki C, Goto N, Kobayashi Y, Ikawa T, Horike M, Saito T, Kurota T, Yamabe K, Okuzumi K (1990) Estimation of P- and S-wave velocities in deep soil deposits for evaluating ground vibrations in earthquake. J Japan Soc for Natural Disaster Scie 9:1-17

Kudo K, Kanno T, Okada H, Ozel O, Erdik M, Sasatani T, Higashi S, Takahashi M, Yoshida (2002) Site specific issues for strong ground motions during the Kocaeli, Turkey earthquake of August 17, 1999, as inferred from array observations of microtremors and aftershocks. Bull Seism Soc Am 92:448-465. doi:10.1785/0120000812

Lemoine A, Douglas J, Cotton F (2012) Testing the applicability of correlations between topographic slope and VS30 for Europe. Bull Seism Soc Am 102:2585-2599. doi:10.1785/0120110240

Lomax A, Snieder R (1994) Finding sets of acceptable solutions with a genetic algorithm with application to surface wave group dispersion in Europe. Geophys Res Lett 21:2617-2620. doi:10.1029/ 94GL02635

Matsuoka M, Wakamatsu K, Fujimoto K, Midorikawa S (2006) Average shear-wave velocity mapping using Japan engineering geomorphologic classification map. Structural Eng./Earthquake Eng. JSCE 23:57-68

McClusky S, Balassanian S, Barka A, Demir A, Ergintav S, Georgiev I, Gurkan O, Hamburger M, Hurst K, Kahle H, Kastens K, Kekelidze G, King R, Kotzev V, Lenk O, Mahmoud S, Mishin A, Nadariya M, Ouzounis A, Paradissis D, Peter Y, Prilepin M, Reilinger R, Sanli I, Seeger H, Tealeb A, Toksöz MN, Veis G (2000) Global Positioning System constraints on plate kinematics and dynamics in the eastern Mediterranean and Caucasus. J Geophys Res 105:5695-5719

MTA (2002) 1:500,000 Scale Geological Map. General Directorate of Mineral Research and Exploration (MTA), Eskisehir Yolu, 06520, Ankara, Turkey. http://www.mta.gov.tr/v2.0/daire-baskanliklari/jed/index.php?id=500bas (last visited 01.11.2015)

Okada H (2003) The microtremor survey method. Geophysical Monograph series No.12, Society of Exploration Geophysicists, Tulsa.

Okada H (2006) Theory of efficient array observations of microtremors with special reference to the SPAC method. Explor Geophys 37:73-85. doi:10.1071/EG06073

Ozalaybey S, Zor E, Ergintav S, Tapırdamaz MC (2011) Investigation of 3-D basin structures in the Izmit Bay area (Turkey) by single-station microtremor and gravimetric methods. Geophys J Int 186:883-894

Ozel O, Cranswick E, Meremonte M, Erdik M, Safak E (2002) Site effects in Avcilar West of Istanbul, Turkey from strong and weak motion data. Bull Seism Soc Am 92:499-508

Ozel O, Sasatani T, Kudo K, Okada H, Kanno T, Tsuno S, Yoshikawa M, Noguchi S, Miyahara M, Goto H (2004) Estimation of S-wave velocity structures in Avcilar-Istanbul from array microtremor measurements. Jour Fac Sci 12-2:115-129, Hokkaido Univ., SerVII (Geophysics)

Picozzi M, Strollo A, Parolai S, Durukal E, Ozel O, Karabulut S, Zschau J, Erdik M (2009) Site characterization by seismic noise in Istanbul, Turkey. J of Soil Dyn and EarthqEng 29:469-482

Şengör AMC (1979) The North Anatolian transform fault: its age, offset and tectonic significance. J Geol Soc Lond 136:269-282

Sørensen M, Oprsal I, Bonnefoy-Claudet S, Atakan K, Martin Mai P, Pulido N, Yalcinar C (2006) Local site effects in Atakoy, Istanbul, Turkey, due to a future large earthquake in the Marmara Sea. Geophys J Int 167:1413-1424

Stewart J, Seyhan E, Boore DM, Campbell KW, Erdik M, Silva WJ, Di Alessandro C, Bozorgnia Y (2012) Site effects in parametric ground motion models for the GEM-PEER Global GMPEs Project. 15th World Conference on Earthquake Engineering (WCEE), 24-28 September 2012, Lisboa, Portugal.

Tekirdag Municipality (2006) Geology Maps of Tekirdag (1:25.000 and 1:12.000 scales), Project for Investigation of Suitability for Settlement.

Wessel P, Smith WHF (1998) New, improved version of the Generic Mapping Tools released. EOS Trans 47:579, AGU 79: no
Yamanaka H (2007) Inversion of surface-wave phase velocity using hybrid heuristic search method. Butsuri Tansa 60:265-275. doi:10.3124/segj.60.265 (in Japanese)

Yamanaka H, Ishida H (1996) Application of genetic algorithms to an inversion of surface-wave dispersion data. Bull Seism Soc Am 86:436-444

Zaineh HE, Yamanaka H, Dakkak R, Khalil A, Daoud M (2012) Estimation of shallow S-Wave velocity structure in Damascus city Syria, using microtremor exploration. J of Soil Dyn and Earthq Eng 39:88-99

Zor E, Özalaybey S, Karaaslan A, Tapırdamaz MC, Özalaybey ÇS, Tarancıoğlu A, Erkan B (2010) Shear wave velocity structure of the Izmit Bay area (Turkey) estimated from active-passive array surface wave and single-station microtremor methods. Geophys J Int 182:1603-1618

\section{Submit your manuscript to a SpringerOpen ${ }^{\odot}$ journal and benefit from:}

- Convenient online submission

- Rigorous peer review

- Immediate publication on acceptance

- Open access: articles freely available online

- High visibility within the field

- Retaining the copyright to your article

Submit your next manuscript at $>$ springeropen.com 